\title{
EPIPRE : a Disease and Pest Management System for Winter Wheat, taking Account of Micrometeorological Factors ${ }^{1}$
}

\author{
by R. RABBINGE ${ }^{2}$ and F.H. RIJSDIJK ${ }^{3}$
}

\begin{abstract}
EPIPRE (EPIdemic PREvention) is a cooperative project for supervised control of diseases and pests in wheat. It operates on a field by field basis. From every wheat field, basic data and field observations are stored in a data bank. Farmers send their field observations to the central team, which enters them in the data bank. Field data are updated daily by means of simplified simulation models. Expected damage and loss are calculated and used in a decision system, that leads to one of three major decisions : " treat", "don't treat", or "make another field observation". Exchange of information between farmers and central team is by mail. In 1978 EPIPRE started with Puccinia striiformis. Since then the number of pests and diseases which are considered have increased, so that in 1981 advice was given for $P$. striiformis, $P$. recondita, Erysiphe graminis, Septoria spp. and the cereal aphids, Sitobion avenae, Metopolophium dirhodum and Rhopalosiphum padi. For each of these pests and diseases predictive methods have been developed using explanatory simulation models as a tool. These explanatory models are based on knowledge of many input relations and some external factors (e.g. temperature) which govern most of the processes of the pest and disease population dynamics. On the basis of a sensitivity analysis with these models simplified decision rules have been developed which are used in the advice system in which updating of the forcing variables is no longer needed.
\end{abstract}

\section{Introduction}

EPIPRE (EPIdemics PREdiction and PREvention) is a system of supervised control of diseases and pests in winter wheat. The participating farmers do their own disease and pest monitoring, according to well defined simple and reliable observation and sampling techniques. Their information is introduced into a computer, which produces recommendations for treatments optimizing towards highest financial return of crop protection. Cereal aphids and five fungus diseases are incorporated in the system. In 1981 some $6 \%$ of Dutch winter wheat acreage was covered. In that year experience with the implementation of this pest and disease control system in Switzerland and Belgium was gained. In 1982 the EPIPRE system will be introduced on an experimental basis in England, Sweden and France, whereas the activities in Belgium and Switzerland may increase. In the Netherlands the system is considered as a full-grown child which is now being further developed by the Extension Service and Research Station for Arable Farming and Field Production of Vegetables in Lelystad.

In this paper we describe aspects of the development, implementation and application of EPIPRE in the Netherlands.

\section{Reasons for EPIPRE and General Set up}

The start of EPIPRE in 1978 was promoted by the heavy epidemics of yellow rust in 1975 and 1977 (Puccinia striiformis Westend.). Then it was decided to use new epidemiological insights and computer simulation models to improve the control of this

1) Paper presented at the EPPO/WMO Symposium on Meteorology for Plant Protection, Geneva (Switzerland), 8-10 March, 1982.

2) Department of Theoretical Production Ecology, Agricultural University, Bornsesteeg 65, 6708 PD Wageningen (Netherlands).

3) Department of Phytopathology, Agricultural University, Binnenhaven 9, 6709 PD Wageningen (Netherlands). 
disease. The project aims were the development, implementation and application of a supervised pest and disease control system that reduces the application of pesticides and decreases the cost/benefit ratio of wheat production in general and of pesticide application in particular. Basic considerations leading to the project were the awareness of the environmental dangers due to increasing use of pesticides in wheat, and doubts on the economic benefits of that approach, even at the presently attained high yield levels of up to $10 \mathrm{t} / \mathrm{ha}$. Information tailored to the farmer's field may help in decision making in pest and disease control. In 4 years the project grew to a supervised control system of the most important pests and diseases in winter wheat in the Netherlands (table 1).

EPIPRE works on a field-by-field basis and gives specific recommendations for every wheat field registered. The core of the system is the data bank and the associated computer administration (fig. 1). The data bank contains specific data on each field including location, sowing time, cultivar, some soil characteristics, herbicide and growthregulator application and nitrogen fertilization. The information per field is stored in the computer and updated whenever additional information on the field is supplied by the farmer. A decision procedure for each disease separately and in combination leads to the recommendation : 1) to make another observation within $X$ days, 2) to apply a spray within a certain period, 3) to do no spraying at all. Fig. 2 shows the principal set up of the data bank organisation. Six different data records are defined: 1) a region record, connecting all fields in a region which enables the research team to produce summaries which show the distribution of diseases and pests in the country ; 2) a cultivar record, connecting all fields with the same cultivar and containing information on susceptibility of the cultivar to the pests and diseases ; 3) a field record, containing all basic information on the field and the changing information concerning the status of the field. Each field record is related to others and contains information on : nitrogen fertilization ; growth regulator and pesticide application; observations, including development stage of the crop; recommendations which have already been given.

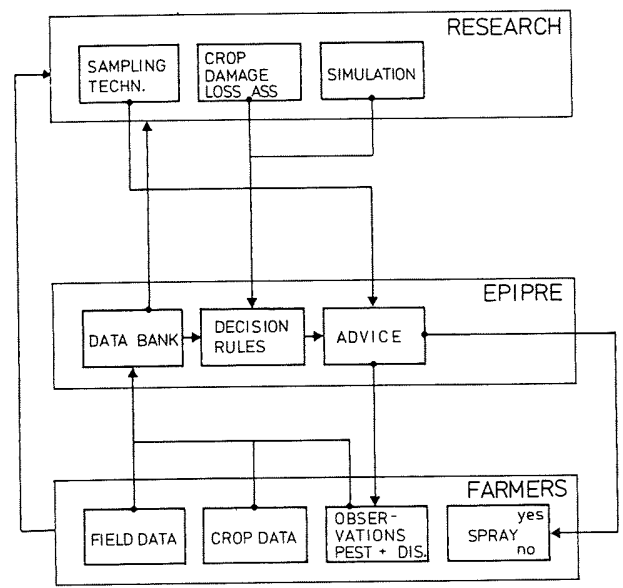

Fig. 1. Organization scheme for EPIPRE in relation to farmers and research organizations.

As farmers do the observations on crop development and pest and disease symptoms themselves, the observation methods need to be simple, reliable and not timeconsuming, and the observation frequency should be indicated by the central system. Participating farmers receive written information including a booklet showing the pest and disease symptoms (Ziekten en Plagen in Graangewassen, 1981, CAD Plantenziekten in de Landbouw, Wageningen) and have field instructions. The observation method is similar 
Table 1. Pests and pathogens included in the EPIPRE system in successive years.

\begin{tabular}{|c|c|c|}
\hline 1978 & Puccinia striiformis Westend. & 400 fields \\
\hline 1979 & $\begin{array}{l}\text { P. striformis } \\
\text { Erysiphe graminis DC. ex Mérat } \\
\text { Sitobion avenae F. }\end{array}$ & 450 fields \\
\hline 1980 & $\begin{array}{l}\text { P. striiformis } \\
\text { E. graminis } \\
\text { Puccinia recondita Rob. } \\
\text { S. avenae } \\
\text { Metopolophium dirhodum (Wk.) } \\
\text { Rhopalosiphum padi (L.) }\end{array}$ & 840 fields \\
\hline 1981 & $\begin{array}{l}\text { P. striiformis } \\
\text { E. graminis } \\
\text { P. recondita } \\
\text { Septoria spp. } \\
\text { S. avenae } \\
\text { M. dirhodum } \\
\text { R. padi }\end{array}$ & 1155 fields \\
\hline
\end{tabular}

for all pests and diseases making use of incidence counts (\% infested tillers) instead of counting actual numbers or determination of infested leaf area.

Communication with the farmers is through the mail (the time between a farmer sending a postcard and receiving a computer-written response is never more than 4 days), and by telephone line in case a rapid response is needed.

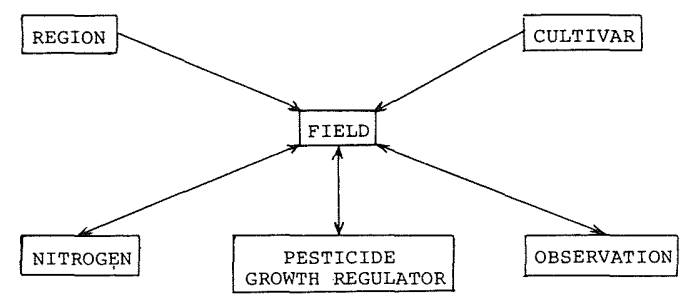

Fig. 2. Data organization of EPIPRE (see text).

\section{Decision Procedure}

The recommendations by the central computer system are based on a decision procedure which uses the farmer's observation for the initial estimate of severity. To get this estimate the farmer's observation is transformed from incidence counts into severity in case of diseases or average number per tiller in case of cereal aphids.

\section{Predicted Severity}

From the severity at the time of observation $\mathrm{X}_{0}$, the severity at the prognosis time $\mathrm{X}_{\mathrm{t}}$ is calculated ( $\mathrm{t}$ is a limited prognosis time), making use of a summary model.

The summary model : $\mathrm{X}_{\mathrm{t}}=\mathrm{X}_{0} \cdot \mathrm{e}^{\mathrm{r} \cdot \mathrm{t}}$

assumes exponential growth of the insect population or disease. This is a valid assumption if the calculation is done for low severity levels $(\leqslant 0.05)$ when there are no limitations for growth, and for a short time period. The length of prognosis time depends on crop 
, 7

development stage. The relative growth rate of the disease depends on development stage of the crop, cultivar, nutrition, soil condition, application of growth regulators etc. Simulation studies on the population dynamics of the pests and diseases have laid the basis for these very simple models.

By the introduction of a crop development stage-dependent relative growth rate and a prognosis time which is also affected by crop development stage, changing weather conditions during crop development are introduced.

\section{Predicted Yield Loss}

With the computed expected severity after a prognosis period, a loss expectation is calculated for each pest and disease. Relations between severity and crop loss show often an S-shaped curve, since with low severities no loss appears and with high severities the loss stabilizes. For decision making in most wheat diseases, only the very beginning of the curve is important as a high severity will lead to disastrous crop losses. When the predicted severity would lead to a crop loss more than the maximum economic threshold (i.e. the loss equals the costs for treatment for only one pest or disease), a control measure is necessary. If combined control measures are possible, this may lower the economic threshold for each of the individual diseases. The calculated loss is expressed as a proportional loss of the expected yield. The expected final yield is based on the farmer's estimate of yield, early in the season, and experience with wheat-growing in the region. The relation between severity and percentage yield loss is affected by the development stage of the crop. In this way the changing susceptibility and effect of potential production of a crop on the effect of disease are introduced.

The calculations for cereal aphids are slightly different. In this case the peak density of the cereal aphids is computed and used to calculate the expected yield loss in $\mathrm{kg}$ wheat $\mathrm{ha}^{-1}$ from damage relations which depend on expected yield and growing conditions. The effect of cereal aphids is superproportional with yield : an aphid density of 15 aphids per tiller in the population peak gives a yield loss of $250 \mathrm{~kg}$ at a production level of $5000 \mathrm{~kg}$ wheat/ha whereas a similar density at a production level of $6500 \mathrm{~kg}$ wheat/ ha may cause a yield loss of $300 \mathrm{~kg}$ and at a production level of $7500 \mathrm{~kg}$ wheat/ha may cause a yield loss of $1000 \mathrm{~kg}$ (Mantel et al., 1982). Thus control of cereal aphids is more important at high than at low production levels.

\section{Basis for Decision Procedure}

The basis for the decision procedure is laid down by simulation studies of the population dynamics of the pests and pathogens. To illustrate this approach, the way cereal aphids are studied will be discussed. In table 2 the different steps which are taken in simulation studies are shown.

The first step, definition of objectives of the study, concerns the increase in insight and knowledge of the reasons and mechanisms of cereal aphid population dynamics. To limit the study, only aphids in cereal fields are considered and not the life cycle of aphids on other host plants. Thus, overwintering and immigration of the cereal aphids to the wheat field are not studied, but only the population dynamics of the aphids from the time that they are present in the wheat field.

To study the numbers of cereal aphids in the field, sound sampling and observation techniques are needed. Indirect methods can be used to determine the time at which migration to cereals begins, but should then be combined with direct population counts when pest management is the aim. A simple and reliable direct observation method, applicable to all three cereal aphid species has been developed (Rabbinge \& Mantel, 1981). 
Table 2. Example of simulation modelling of cereal aphid populations.

\begin{tabular}{|c|c|}
\hline Steps in simulation & e.g. for Sitobion avenae \\
\hline 1. Define objectives & explain and predict population dynamics \\
\hline 2. Define limits of the system & one field of winter wheat \\
\hline $\begin{array}{l}\text { 3. Conceptualize the elements of the system } \\
\text { (state variables, rate variables, auxiliary varia- } \\
\text { bles, forcing variables) }\end{array}$ & relational diagrams \\
\hline 4. Quantification of relations & experiments and literature \\
\hline 5. Verification & $\begin{array}{l}\text { compare model output with data of } 1976 \text { and } \\
1977 \text { at one location, partly used for parametrisa- } \\
\text { tion }\end{array}$ \\
\hline 6. Validation & test model at several locations in different years \\
\hline 7. Sensitivity analysis & $\begin{array}{l}\text { demonstrate the relative importance of different } \\
\text { relations, e.g. temperature }\end{array}$ \\
\hline 8. Simplification & $\begin{array}{l}\text { summary model, exponential growth dependent } \\
\text { on physiological time }\end{array}$ \\
\hline
\end{tabular}

In this method, infestation levels (percentage infested tillers) are determined which can be translated into an average number of cereal aphids per tiller. The transformation accounts for the patchy distribution of cereal aphids in the field. The transformation uses a linear relation between the probit value of the percentage of tillers infested with aphids and the natural logarithm of the average number of aphids per tiller. As the numbers of cereal aphids vary considerably from year to year and within a season from field to field, observations in each field are needed to quantify the population density at the beginning of the season. This observation method of determining infestation levels is used in EPIPRE.

In Dutch cereal crops, the first aphids are usually found in May at booting stage (Decimal Code 40). From that time the number of aphids increases steadily. At anthesis (flowering) there may already be large numbers of cereal aphids. After flowering (DC 69), immigration usually decreases and population growth is then mainly due to reproduction of cereal aphids which immigrated earlier. Nearly always, irrespective of season or field considered, the population peak of cereal aphids is found at the late milky-ripe stage (DC 77). Although the details may vary between fields and years, a general pattern of population upsurge and decline is present in all cases. The cereal aphid population is large in the period after flowering and peaks at the late milky-ripe stage (DC 77). The decline of the population, induced by emigration of the aphids, is enhanced by parasites, predators and Entomophthora spp. This general pattern and the reasons for it can be demonstrated by means of the simulation models which have been constructed on the basis of different basic data on cereal aphid biology (table 2, steps 5 and 6). These models take into account the dynamics of the host crops, the characteristics of the cereal aphids and those of their natural enemies (Carter et al., 1982 ; Rabbinge et al., 1979). Tests of the models to control their outcomes have been performed and show that they may give a sound explanation for the population upsurge, the peak and the crash of the population.

Sensitivity analyses using these tested and validated simulation models showed that the effect of natural enemies on the population upsurge is limited and that changes in environmental conditions also have a limited effect on the size of the population peak. When temperatures during kernel filling are higher than normal, crop development is faster than normal and population growth of the cereal aphids reaches doubling times of 2-3 days. Nevertheless, the population peak is not higher, because emigration starts earlier due to a rapid change in crop condition as a result of rapid crop development. Cool weather 
leads to an extended crop development period and thus promotes high yield but it also induces an extended period of population growth of cereal aphids and so higher peak densities.

In the foregoing, cereal aphids have been discussed in general, disregarding the species. The monoecious species Sitobion avenae with its clear preference for the ears has a pattern of population development on the wheat crop which resembles that of Metopolophium dirhodum (Ankersmit \& Carter, 1981), with its different life cycle and marked preference for the leaves. In both species, population growth is exponential until the milky-ripe stage, at the end of which a peak is reached, due to emigration, wing formation no longer being suppressed (Rabbinge et al., 1979). The other cereal aphid which frequently occurs in western and northern Europe, Rhopalosiphum padi, very rarely causes important damage in winter wheat and is not therefore considered separately. Because of the resemblance in epidemiology between the cereal aphids, the three species are not considered separately in EPIPRE. The same epidemiological model is used for all three species, i.e. the methods and parameters to predict the population density are the same for the three species. On the basis of the sensitivity analyses with the extensive population models, so-called summary models have been developed (Carter et al., 1982). These summary models use the average number of cereal aphids per tiller, determined as described above, as an input and compute the peak density of the cereal aphids at development stage DC 77. The computation applies a simple exponential growth formula, using a relative growth rate which depends only on crop development stage, and an estimate for the time period between the actual development stage and DC 77 . When weather conditions deviate from the climatic conditions of that particular region, the input data for the decision rules, especially crop development stage, are brought up to date and new predictions are made. In this way predictions may differ from field to field, since initial conditions of crop development and aphid population density, and weather conditons, may be different.

Unfortunately, available knowledge on the potential of natural enemies to attack cereal aphids, including fungal pathogens (Entomophthora spp.), is so limited that they cannot yet be incorporated into the decision rules. The perspectives for using natural enemies and fungal pathogens in biological control are at this moment low, but research being done at different places may lead to better methods and control agents, and thus will necessitate the introduction of these natural enemies into the decision rules.

\section{Results of EPIPRE}

The EPIPRE system has been implemented and improved in the Netherlands since 1978. The number of participating fields started with some 400 in 1978 and some 1100 in 1981. About $6 \%$ of the Dutch winter wheat acreage is covered. As shown in table 1, the number of pests and diseases incorporated in the system has increased considerably, a fairly complete package being offered nowadays.

The population dynamics of each of the diseases may differ and their crop loss relations may vary considerably. For each of the diseases appropriate summary models and computation rules are introduced.

During the years of experience with EPIPRE it has become clear that the confidence in the recommendations has grown. In 1980, $38 \%$ of the participating fields were treated according to EPIPRE, and in 1981, $54 \%$. The reluctance of farmers to follow the EPIPRE recommendations completely may be explained by the fact that significantly fewer treatments are recommended in comparison with other sources, such as the Extension Service and the chemical industry. However it is not to be expected that such a system ever will reach a $100 \%$ score, since there are often good reasons for a farmer not to 
Table 3. Comparison between net yield of fields treated according to EPIPRE and fields treated * more than EPIPRE $\nsim$ in 1981.

\begin{tabular}{|c|c|c|c|}
\hline Yield class & $<6$ ton $\mathrm{ha}^{-1}$ & $6-8$ ton ha ${ }^{-1}$ & $>8$ ton $\mathrm{ha}^{-1}$ \\
\hline $\begin{array}{l}\text { Net yield } \\
\text { EPIPRE }\end{array}$ & 5.34 & 6.90 & 8.16 \\
\hline $\begin{array}{l}\text { Net yield } \\
\text { \& more than EPIPRE }\end{array}$ & 4.93 & 6.77 & 8.13 \\
\hline $\begin{array}{l}\text { Costs of treatment } \\
\text { EPIPRE in tons ha }\end{array}$ & 0.15 & 0.23 & 0.31 \\
\hline $\begin{array}{l}\text { Costs of treatment } \\
\text { \& more than EPIPRE } \\
\text { in tons } \mathrm{ha}^{-1}\end{array}$ & 0.45 & 0.41 & 0.45 \\
\hline $\begin{array}{l}\% \text { of fields treated } \\
\text { in accordance with } \\
\text { EPIPRE }\end{array}$ & 75 & 57 & 41 \\
\hline Number of fields & 69 & 524 & 263 \\
\hline
\end{tabular}

obey the recommendations. The proof of the system is the participation of farmers, as they pay for their recommendations.

A comparison of participating farmers' fields with EPIPRE recommendations and other recommendation sources show that EPIPRE recommends significantly less treatments than other sources but that the net yield is similar or slightly higher (table 3 ). The farmers with low yield levels are more inclined to follow EPIPRE recommendations than farmers with high yield levels. The disease and pest situation has been quite different in the different years. In 1978, 1979, and 1980 there were virtually no important diseases, and only cereal aphids (especially $M$. dirhodum) were important in 1979. In 1981 a large number of fields suffered from powdery mildew and cereal aphids, mainly $S$. avenae, but Septoria spp. were also important. Mildew was important early in the season and Septoria spp. and cereal aphids after flowering.

\section{Discussion}

Although EPIPRE has only a short history it appears very clearly that there exists a demand for a supervised pest and disease management system for winter wheat.

This system or infrastructure enables the scientist to channel his information concerning population dynamics of pests and diseases and crop loss directly to the farmer's field. Changes in cultivars, agricultural methods, susceptibility and virulence may be introduced immediately into the system and may alter recommendations. The advantages of EPIPRE for the farmers are the direct ties with research and the reminders to monitor their wheat crop in a particular way. For the research workers it has the advantage that new problems arising in the field are immediately formulated and incorporated.

For agriculture as a whole, this supervised system has the advantage of less use of pesticides and a decrease in the risk for development of resistance of fungi and insects to pesticides. In the future the system may be extended into a complete crop management system in which nitrogen fertilization, weed control and other agronomical measures are incorporated.

The system is now run centrally on a big computer, storing data of many fields. In the near future EPIPRE may be available as a software package for microcomputers which can be used by the farmers, individually or in groups on their own equipment. 
The role of meteorological data in the EPIPRE system is limited, as the repetitive observations and the introduction of physiological time (crop development stage) appear to be sufficiently accurate. Whenever detailed weather data is needed for other diseases, this may be incorporated into the central system as the central computer is connected to the computer of the Royal Netherlands Meteorological Institute. If microcomputers are used, meteorological data-measuring equipment should be used which is adapted to the size of these systems.

In this way, these management systems may help to reach the final aim of an agriculture in which energy and pesticide use is optimized instead of maximized.

\section{EPIPRE : système d'avertissement dirigé pour la protection du blé d'hiver tenant compte de la microclimatologie}

EPIPRE (EPIdemic PREvention) est un programme coopératif de lutte dirigée contre les maladies et les ravageurs du blé d'hiver, permettant d'émettre des conseils individualisés. Les données de base et les observations faites par l'exploitant pour chaque champ de blé sont enregistrées par une banque de données. Ces observations sont journellement mises à jour au moyen de modèles simplifiés de simulation. Les dégâts et les pertes auxquels il faut s'attendre sont calculés et introduits dans un système de décision, qui conduit à l'information suivante : " traiter », « ne pas traiter ", " envoyer complément d'observations faites au champ ". L'échange d'informations entre les exploitants et l'équipe centrale se fait par courrier. En 1978, EPIPRE s'est limité à Puccinia striiformis. Depuis, le nombre de ravageurs et de maladies considérés a augmenté, et en 1981 les avertissements ont pu être faits pour $P$. striiformis, $P$. recondita, Erysiphe graminis, Septoria spp. et les pucerons des céréales : Sitobion avenae, Metopolophium dirhodum et Rhopalosiphum padi. Pour chacun de ces ravageurs ou maladies, des méthodes de prévision utilisant des modèles explicatifs de simulation ont été mises au point. Ces modèles se basent sur la connaissance de nombreuses relations qui sont considérées en entrée et de quelques facteurs externes (par exemple la température) qui gouvernent la plupart des processus de la dynamique des populations de ravageurs ou du développement des maladies. Sur la base d'une analyse de la sensibilité de ces modèles, des lois simplifiées de décision ont été déterminées. Elles sont utilisées dans le système d'avertissement dans lequel la mise à jour des variables à caractère impérieux n'est plus nécessaire.

ЭПИПРЕ - СИСТЕМА РЕГУЛИРОВАНИЯ ЗАБОЛЕВАНИЙ И ВРЕДИТЕЛЕЙ ДЛЯ ОЗИМОЙ ПНЕНИҢ УЧЕТ МИКРОМЕТЕОРОЛОГИЧЕСКИХ ФАКТОРОВ

ЭПИПРЕ (ПРЕдупреждение ЭПИдемий) представляет собой совместный проект, предназначенный для комплексной борьбы с заболеваниями и вредителями пшеницы. Проект функционирует на основе индивидуальной полевой оценки. Основные данные и полевые наблюдения, собираемые фермерами на каждом поле пшеницы, поступают в центральный отдел, где производится их ввод в банк данных. Ежедневно проводится обновление введенных полевых данных с помощыо упрощенных имитационных моделей. Ожидаемые потери и ущерб рассчитываются и используются в системе принятия решений, которая вырабатывает одно из крупных решений: "обрабатывать", "не обрабатывать", "сделать еще одно полевое наблюдение". Обмен информацией между фермерами и центральньм отделом производится по почте. В 1978 году проект ЭПиПРЕ начал работать с Puccinia striformis. С тех пор стали в стали вестись наблюдения над P.striliformis, P. recondita, Erysiphe graminis, Septoria, а также для тлей злаковых, Sitobion avenae, Metopolophium dirhodum и Rhopalosiphum padi. Для каждого из этих вредителей и заболеваний были разработаны методы прогноза с использованием базовых имитационных моделей. Эти базовые имитационные модели были построены на взанмодействии большого числа вводимых данных и нескольких внешних факторов (например, температуры), которые управляют большей частью процессов динамики популяции вредителей и динамики заболеваний. На основе анализа чувствительности этих моделей были разработаны упрощенные правила. принятия решений, которые используются в рамках такой консультативной системы, в которой обновление вводимых переменных больше не требуется. 


\section{REFERENCES}

ANKERSMIT, G.W. \& CARTER, N. (1981). Comparison of the epidemiology of Metopolophium dirhodum and Sitobion avenae on winter wheat. Neth. J. Pl. Path. $87: 71-81$

CARTER, N., RABBINGE, R. \& DIXON, A.F.G. (1982). Cereal aphid populations : biology, simulation and prediction Pudoc, Wageningen, Netherlands, $91 \mathrm{pp}$.

MANTEL, W.P., RABBINGE, R. \& SINKE, J. (1982). (Effects on leaf aphids on winter wheat yields) Gewasbescherming (in press).

RABBINGE, R., ANKERSMIT, G.W. \& PAK, G.A. (1979). Epidemiology and simulation of population development of Sitobion avenae in winter wheat. Neth. J. Pl. Path. $85: 197-220$.

RABBINGE, R. \& MANTEL, W.P. (1981). Monitoring for cereal aphids in winter wheat. Neth. J. Pl. Path. $87: 25-29$ 
